Pesq. Vet. Bras. 37(11):1187-1192, novembro 2017 DOI: $10.1590 / \mathrm{S} 0100-736 \mathrm{X} 2017001100001$

\title{
Antimicrobial susceptibility patterns of Brazilian Haemophilus parasuis field isolates ${ }^{1}$
}

\author{
Michela Miani², Monique S. Lorenson², João A. Guizzo², Julia P. Espíndola², \\ Elías F. Rodríguez-Ferri ${ }^{3}$, César B. Gutiérrez-Martín ${ }^{3}$, Luiz C. Kreutz ${ }^{2}$ \\ and Rafael Frondoloso ${ }^{2 *}$
}

\begin{abstract}
Miani M., Lorenson M.S., Guizzo J.A., Espíndola J.P., Rodríguez-Ferri E.F., Gutiérrez-Martín C.B., Kreutz L.C. \& Frandoloso R. 2017. Antimicrobial susceptibility patterns of Brazilian Haemophilus parasuis field isolates. Pesquisa Veterinária Brasileira 37(11):1187-1192. Laboratório de Microbiologia e Imunologia Avançada, Universidade de Passo Fundo, Campus I, Edifício G3, Bairro São José, Passo Fundo, RS 99052-900, Brazil. E-mail: rfran@upf.br

Haemophilus parasuis is the etiological agent of Glässer's disease (GD), an ubiquitous infection of swine characterized by systemic fibrinous polyserositis, polyarthritis and meningitis. Intensive use of antimicrobial agents in swine husbandries during the last years triggered the development of antibiotic resistances in bacterial pathogens. Thus, regular susceptibility testing is crucial to ensure efficacy of different antimicrobial agents to this porcine pathogen. In this study, 50 clinical isolates from South Brazilian pig herds were characterized and analyzed for their susceptibility to commonly used antibiotic. The identification and typing of clinical isolates was carried out by a modified indirect hemagglutination assay combined with a multiplex PCR. The susceptibility of each isolate was analyzed by broth microdilution method against a panel of 21 antimicrobial compounds. We found that field isolates are highly resistance to gentamycin, bacitracin, lincomycin and tiamulin, but sensitive to ampicillin, clindamycin, neomycin, penicillin, danofloxacin and enrofloxacin. Furthermore, an individual susceptibility analysis indicated that enrofloxacin is effective to treat clinical isolates with the exception of those classified as serovar 1 . The results presented here firstly demonstrate the susceptibility of Brazilian clinical isolates of $H$. parasuis to antimicrobials widely used by swine veterinary practitioners and strengthen the need to perform susceptibility test prior to antibiotic therapy during GD outbreaks. In addition, because only six antimicrobial drugs (28.6\%) were found effective against field isolates, a continuous surveillance of the susceptibility profile should be of major concern to the swine industry.
\end{abstract}

INDEX TERMS: Haemophilus parasuis, MIC, antimicrobial susceptibility, clinical isolates, swine.

RESUMO.- [Perfil de susceptibilidade antimicrobiana de isolados clínicos brasileiros de Haemophilus parasuis.] Haemophilus parasuis é o agente etiológico da doença de Glässer (GD), um processo infeccioso que acomete suínos e que se caracteriza por poliserosites fibrinosas sistêmicas, poliartrites e meningites. 0 uso intensivo de

\footnotetext{
${ }^{1}$ Received on April 21, 2016.

Accepted for publication on November 7, 2016

${ }^{2}$ Laboratório de Microbiologia e Imunologia Avançada, Universidade de Passo Fundo, Campus I, Bairro São José, Passo Fundo, RS 99052-900, Brazil. *Corresponding author: rfran@upf.br

${ }^{3}$ Departamento de Sanidad Animal, Universidad de León, Campus de Vegazana, León, CP 24007, España.
}

agentes antimicrobianos na produção de suínos, durante os últimos anos, tem disparado a seleção de cepas bacterianas resistentes a antibióticos. Desta maneira, a avaliação rotineira de susceptibilidade torna-se crucial para assegurar a correta seleção de um antimicrobiano eficaz contra este patógeno. Neste estudo, analisou-se a susceptibilidade antimicrobiana de 50 isolados clínicos de $H$. parasuis procedentes de granjas localizadas na região sul do Brasil. A identificação e tipificação dos isolados clínicos foi realizada através de uma PCR multiplex combinada com o teste de hemaglutinação indireta modificada. A susceptibilidade de cada isolado foi analisada pelo método de microdiluição em caldo utilizando-se um painel composto por 21 agentes antimicrobianos. Os resultados deste estudo indicam que 
as cepas clínicas de H. parasuis apresentam alta resistência à gentamicina, bacitracina, lincomicina e tiamulina, no entanto, são susceptíveis a ampicilina, clindamicina, neomicina, penicilina, enrofloxacina e danofloxacina. A análise de susceptibilidade realizada dentro de cada grupo de cepas de um mesmo sorovar indicou que a enrofloxacina é o antibiótico mais efetivo para tratar todos isolados clínicos com exceção daqueles pertencentes ao sorovar 1 . Em termos gerais, neste trabalho, demonstra-se o perfil de susceptibilidade de isolados clínicos de H. parasuis aos antimicrobianos comumente utilizados pelos médicos veterinários especialistas em suínos, e reforça-se a necessidade da realização de testes de susceptibilidade antes do início da terapia com antibióticos durante surtos de DG. Além disso, como somente seis antimicrobianos (28.6\%) foram efetivos contra os isolados clínicos, uma vigilância contínua do perfil de susceptibilidade aos antimicrobianos deve ser de grande preocupação para a indústria de suínos.

TERMOS DE INDEXAÇ̃̃̃: Haemophilus parasuis, MIC, susceptibilidade antimicrobiana, isolados clínicos, suínos.

\section{INTRODUCTION}

Haemophilus parasuis is a commensal bacterium of the upper respiratory tract of swine that under stressful circumstances might cause Glässer's disease (GD) (Costa-Hurtado \& Aragon 2013). This ubiquitous infectious disease occurs mainly in piglets and is characterized by fibrinous polyserositis, polyarthritis and meningitis (Oliveira et al. 2001). Fifteen $H$. parasuis serovars have been identified to date but the continuous isolation of non-typable clinical isolates indicates a wider degree of diversity within this organism (Rafiee \& Blackall 2000). Although there are four global commercial vaccines available and vaccination is widespread, outbreaks of GD are not uncommon in vaccinated swine herds, causing important economic losses in pig industry.

In addition to vaccination, antimicrobials agents are routinely used for the control and treatment of H. parasuis-related porcine respiratory diseases (De la Fuente et al. 2007 ) and currently $\beta$-lactams (ampicillin and penicillin), phenicols (florfenicol), macrolides (erythromycin, tilmicosin, tylosin tartrate), potentiated sulphonamides and tetracyclines (chlortetracycline, oxitetracycline and tetracyclin) are being used to treat $H$. parasuis outbreaks in pig farms (Dayao et al. 2014). However, the indiscriminate use of antibiotic hastens the development of bacterial resistance (Aarestrup et al. 2008).

The antimicrobial resistance profile of $H$. parasuis clinical isolates have been investigated in China (Zhou et al. 2010), Denmark (Aarestrup et al. 2004), Australia (Dayao et al. 2014), Spain and United Kingdom (De la Fuente et al. 2007). The continuing surge of antibiotic-resistant strains makes it difficult to predict treatment efficacy of diseased piglets without prior susceptibility testing. Thus, regular susceptibility testing is crucial to ensure the efficacy of different antimicrobial agents to $H$. parasuis (Aarestrup et al. 2008).

Brazil is one of the most important countries in the pig industry, but little is known about $H$. parasuis epidemiolo- gy, serovar prevalence and antimicrobial susceptibility patterns of clinical isolates. Outbreaks of GD in vaccinated her$\mathrm{ds}$ and resistance to treatment with antibiotic have been a major issue amongst swine veterinary clinicians and diagnosticians. Serotyping of field isolates and testing to antimicrobial susceptibility indicated that several outbreaks were caused by serovars not included in commercial vaccines and the emergence of resistant isolated to commonly used antibiotics. Thus, the aim of this this study was to evaluate the antimicrobial susceptibility of $H$. parasuis field isolates and to indicate antimicrobials molecules and their respective concentrations that could be used to control GD outbreaks.

\section{MATERIALS AND METHODS}

Haemophilus parasuis reference strains and bacterial isolation. The 15 reference strains of $H$. parasuis (№4, SW140, SW114, SW124, Nagasaki, 131, 174, C5, D74, H555, H465, H425, 84-17975, 84-22113 and 84-15995) were used. Bacteria were grown in pleuropneumonia-like organism (PPLO, Himedia, India) broth supplemented with $2.5 \mathrm{mg} / \mathrm{ml}$ glucose (Sigma-Aldrich, Germany) and $75 \mu \mathrm{g} / \mathrm{ml}$ nicotinamide adenine dinucleotide (NAD) (Sigma-Aldrich) and incubated for 24-36 h under shaking (250rpm, New Brunswick, Germany) at $37^{\circ} \mathrm{C}$ in an atmosphere containing $5 \% \mathrm{CO}_{2}$.

In addition, 50 clinical isolates collected between 2012 and 2014 were selected randomly from the bacterial collection of Laboratory of Microbiology and Advanced Immunology, Universidade de Passo Fundo, Passo Fundo, RS, Brazil. All isolates were obtained from pigs suffering from fibrinous pericarditis and were grown in PPLO broth supplemented as described above. The samples came from pig farms located in the north region of Rio Grande do Sul (20 isolates), west of Santa Catarina (15 isolates) and southwest of Paraná (15 isolates).

Serotyping of clinical isolates. Clinical isolates were molecular typing by a multiplex PCR designed by Howell et al. (2015). The altered indirect hemagglutination method using sheep red blood cells treated with tannic acid (Lorenson et al. 2016) was used to discriminate between serovar (SV) 5 and SV 12.

Antimicrobial plate preparation. Antimicrobial solutions were diluted in supplemented PPLO and prepared according to Clinical and Laboratory Standard Institute guidelines (CLSI 2013) or used at the following concentrations: ampicillin (AMP; 0.12$16 \mu \mathrm{g} / \mathrm{ml}$ ); bacitracin (BAC; $1-64 \mu \mathrm{g} / \mathrm{ml}$ ); cephalotin (CF; 1-32 $\mu \mathrm{g}$ / $\mathrm{ml}$ ); chlortetracycline (CTET; $0.25-8 \mu \mathrm{g} / \mathrm{ml}$ ); clindamycin (CLI; $0.25-16 \mu \mathrm{g} / \mathrm{ml}$ ); danofloxacin (DANO; $0.12-4 \mu \mathrm{g} / \mathrm{ml}$ ); enrofloxa-

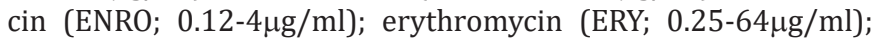
florfenicol (FFC; $0.12-8 \mu \mathrm{g} / \mathrm{ml}$ ); gentamicin (GEN; 0.5-8 $\mu \mathrm{g} / \mathrm{ml}$ ); Kanamycin (KAN; $0.5-2 \mu \mathrm{g} / \mathrm{ml}$ ); lincomycin (LCM; 0.12-1 $\mu \mathrm{g}$ / $\mathrm{ml}$ ); neomycin (NEO; $0.5-32 \mu \mathrm{g} / \mathrm{ml}$ ); oxytetracyclin (OXY; 0.25 $16 \mu \mathrm{g} / \mathrm{ml}$ ); penicillin (PEN; $0.12-8 \mu \mathrm{g} / \mathrm{ml}$ ); spectinomycin sulfate (SPE; $2-64 \mu \mathrm{g} / \mathrm{ml}$ ); trimethoprim:sulfamethoxazole (SXT; 0.5:9.5$2: 38 \mu \mathrm{g} / \mathrm{ml}$ ); tetracyclin (TCN; $0.12-64 \mu \mathrm{g} / \mathrm{ml}$ ); tiamulin (TIA; $0.25-32 \mu \mathrm{g} / \mathrm{ml}$ ); tilmicosin (TIL; $0.5-32 \mu \mathrm{g} / \mathrm{ml}$ ); tylosin tartrate (TYLT; $1-64 \mu \mathrm{g} / \mathrm{ml}$ ). All antimicrobial agents (pure powders) were purchased from Sigma-Aldrich, except ampicillin (Roche, Switzerland). Gentamicin was a liquid standard solution obtained from the Gibco, CA.

Broth microdilution method. $H$. parasuis was adjusted to 0.15 optical density $\left(\mathrm{A}_{600 \mathrm{~nm}}\right)\left(10^{8}\right.$ bacteria/ml, equivalent to 0.5 MacFarland standard) in supplemented PPLO. The concentration of bacteria used in this experiment was $5 \times 10^{6}$ bacteria/well. Antimicrobials were serially diluted (factor 2 ) at the indicated con- 
centrations. Bacteria were added to the wells containing antimicrobial agents and incubated for 24-36 h under shaking (200 rpm, New Brunswick) at $37^{\circ} \mathrm{C}, 5 \% \mathrm{CO}_{2}$.

The minimal inhibitory concentration (MIC) was defined as the lowest concentration of the antibiotics at which no visible bacterial growth was detected (CLSI 2013). Actinobacillus pleuropneumoniae ATCC 27090 was included as control. The analysis of each isolate was performed in duplicate.

\section{RESULTS}

The results of the susceptibility testing and the MICs values, $\mathrm{MIC}_{50}$ and $\mathrm{MIC}_{90}$, of the $15 \mathrm{H}$. parasuis reference serovars are shown in Table 1 . All of them were susceptible to $\leq 0.12 \mu \mathrm{g} / \mathrm{ml}$ of ENRO and PEN, and 14 of 15 strains (93.3\%) were susceptible to DANO and TCN. All these strains were susceptible to the antimicrobial concentration range used with the exception of BAC and GEN, to which all or 14 of the 15 strains (93.3\%) were resistant respectively.

Prior to susceptibility testing, the 50 clinical isolates were serotyped. Serovar 4 was the most prevalent (24\%) followed by SV 5 (20\%), SV 1 (14\%), SV 12 (14\%), and SV $14(12 \%)$. SV 2 was detected in only two clinical isolates while $12 \%$ of clinical isolates were non-typeable. Several of the 50 clinical isolates tested were to some extent resistant to the antimicrobial concentrations used (Table 2). For instance, $88 \%$ and $82 \%$ of clinical isolates were resistant $\left(\mathrm{MIC}_{50}\right.$ of $>64 \mu \mathrm{g} / \mathrm{ml}$ ) to BAC and GEN respectively; $42 \%$ of them were resistant to up to $64 \mu \mathrm{g} / \mathrm{ml} \mathrm{LCM}\left(\mathrm{MIC}_{50}\right.$ of $0.5 \mu \mathrm{g} /$ $\mathrm{ml}$ ) and $48 \%$ was resistant beyond TIA breakpoint (MIC of $8 \mu \mathrm{g} / \mathrm{ml}$ ). Except for NEO, the remaining antimicrobial agents showed at least one clinical isolate which was capable of growing at $>64 \mu \mathrm{g} / \mathrm{ml}$ (Table 2 ).

MIC patterns of the clinical isolates of the same serovar were compared (Table 3). Field isolates belonging to the same serovar shared a similar susceptibility profile; however, a different susceptibility profile was observed amongst different serovars, with the exception of a well spread resistance profile to BAC and GEN. For instance, all isolates belonging to SV 2, SV 5, SV 11 and SV 12 were susceptible to CLI $\left(\mathrm{MIC}_{50}\right.$ of $0.25 \mu \mathrm{g} / \mathrm{ml}$ ) while different degrees of resistance were observed for SV 15. Interestingly, SV 12 was the most resistant to $\mathrm{LCM}\left(\mathrm{MIC}_{90}\right.$ of $\left.>64 \mu \mathrm{g} / \mathrm{ml}\right)$ compared to other serovars to which only a moderate resistance was observed. Non-typable isolates were heterogeneous in their susceptibility profile. Nonetheless, they were sensitive to ENRO $\left(\mathrm{MIC}_{90}\right.$ of $\left.0.5 \mu \mathrm{g} / \mathrm{ml}\right)$ and were all resistant to BAC (Table 3).

\section{DISCUSSION}

The course of GD is often short and many sick piglets die if untreated. H. parasuis is susceptible to many antimicrobials, but the sensitivity pattern of isolates may vary over time. Thus, periodic susceptibility evaluation of clinical isolates to most commonly used antimicrobials is recommended for appropriate treatment. All antibiotics tested in this study are registered for use in Brazil, with the exception of spectinomycin.

The antimicrobial agents belonging to the fluoroquinolone family, DANO and ENRO, were developed for veterinary use (Lopez-Cadenas et al. 2013, Shojaee Aliabadi and Lees 2003) and have the best efficiency profile, displaying a $\mathrm{MIC}_{90}$ of 0.12 and $0.25 \mu \mathrm{g} / \mathrm{ml}$ respectively. No resistance to ENRO was reported in clinical isolates from United Kingdom (De la Fuente et al. 2007) and Switzerland (Wissing et al. 2001). However, a different profile was observed in Spain and South China, where $20 \%$ and $70.9 \%$ of isolates were resistant respectively to ENRO and DANO (De la Fuen-

Table 1. Minimum inhibitory concentration (MIC) of antimicrobials to the 15 reference strains of Haemophilus parasuis

\begin{tabular}{|c|c|c|c|c|c|c|c|c|c|c|c|c|c|c|}
\hline \multirow[t]{2}{*}{ Antimicrobial } & \multirow{2}{*}{$\begin{array}{l}\text { QC ranges } \\
(\mu \mathrm{g} / \mathrm{ml})\end{array}$} & \multicolumn{11}{|c|}{ Number of reference strains with MIC $(\mu \mathrm{g} / \mathrm{ml})$} & \multirow[t]{2}{*}{$\mathrm{MIC}_{50}$} & \multirow[t]{2}{*}{$\mathrm{MIC}_{90}$} \\
\hline & & 0.12 & 0.25 & 0.5 & 1 & 2 & 4 & 8 & 16 & 32 & 64 & $>64$ & & \\
\hline Ampicillin (AMP) & $0.12-16$ & 11 & 3 & 1 & & & & & & & & & 0.12 & 0.25 \\
\hline Bacitracin (BAC) & $1-64$ & & & & & & & & & & & 15 & $>64$ & $>64$ \\
\hline Cephalotin (CF) & $1-32$ & & & & 14 & 1 & & & & & & & 1 & 1 \\
\hline Chlortetracycline (CTET) & $0.25-8$ & & 7 & & 4 & 3 & 1 & & & & & & 1 & 2 \\
\hline Clindamycin (CLI) & $0.25-16$ & & 11 & 2 & & & & & 2 & & & & 0.25 & 0.5 \\
\hline Danofloxacin (DANO) & $0.12-4$ & 14 & & 1 & & & & & & & & & 0.12 & 0.12 \\
\hline Enrofloxacin (ENRO) & $0.12-4$ & 15 & & & & & & & & & & & 0.12 & 0.12 \\
\hline Erythromycin (ERY) & $0.25-64$ & & 8 & 5 & 1 & 1 & & & & & & & 0.25 & 1 \\
\hline Florfenicol (FFC) & $0.12-8$ & & & & 6 & 6 & 1 & 1 & & & & 1 & 2 & 8 \\
\hline Gentamicin (GEN) & $0.5-8$ & & & & & & & 1 & & & & 14 & $>64$ & $>64$ \\
\hline Kanamycin & $0.5-2$ & & & 12 & & 3 & & & & & & & 0.5 & 2 \\
\hline Lincomycin (LCM) & $0.12-1$ & 6 & 3 & 3 & 2 & & & & & & & 1 & 0.25 & 1 \\
\hline Neomycin (NEO) & $0.5-32$ & & & 2 & 2 & 4 & 5 & 2 & & & & & 2 & 8 \\
\hline Oxytetracycline (OXY) & $0.25-16$ & & 13 & 2 & & & & & & & & & 0.25 & 0.5 \\
\hline Penicillin (PEN) & $0.12-8$ & 15 & & & & & & & & & & & 0.12 & 0.12 \\
\hline Spectinomycin (SPE) & $2-64$ & & & & & 8 & 4 & 3 & & & & & 2 & 8 \\
\hline SXT & $0.5-2$ & & & 15 & & & & & & & & & 0.5 & 0.5 \\
\hline Tetracyclin (TCN) & $0.12-64$ & 14 & & 1 & & & & & & & & & 0.12 & 0.12 \\
\hline Tiamulin (TIA) & $0.25-32$ & & 1 & & 1 & 1 & 4 & 3 & 2 & 3 & & & 8 & 32 \\
\hline Tilmicosin (TIL) & $0.5-32$ & & & 14 & & 1 & & & & & & & 0.5 & 0.5 \\
\hline Tylosin tartrate (TYLT) & $1-64$ & & & & 2 & 1 & 8 & 4 & & & & & 4 & 8 \\
\hline
\end{tabular}

$\mathrm{MIC}_{50}$ and $\mathrm{MIC}_{90}=$ minimal inhibitory concentrations of antimicrobial agent being able to inhibit the growth of $50 \%$ and $90 \%$ of isolates, respectively; QC range = the concentration used for each antimicrobial; SXT = trimethoprim and sulphamethoxazole was used at the ratio 1:19; Vertical bars = breakpoint. 
Table 2. Minimum inhibitory concentration (MIC) distribution of 50 clinical isolates of Haemophilus parasuis

\begin{tabular}{|c|c|c|c|c|c|c|c|c|c|c|c|c|c|c|}
\hline \multirow[t]{2}{*}{ Antimicrobials } & \multirow{2}{*}{$\begin{array}{c}\text { QC ranges } \\
(\mu \mathrm{g} / \mathrm{ml})\end{array}$} & \multicolumn{11}{|c|}{ Number of clinical isolates with MIC $(\mu \mathrm{g} / \mathrm{ml})$} & \multirow[t]{2}{*}{$\mathrm{MIC}_{50}$} & \multirow[t]{2}{*}{$\mathrm{MIC}_{90}$} \\
\hline & & 0.12 & 0.25 & 0.5 & 1 & 2 & 4 & 8 & 16 & 32 & 64 & $>64$ & & \\
\hline Ampicillin (AMP) & $0.12-16$ & 11 & 3 & 9 & 10 & 12 & 2 & & & & & 3 & 1 & 4 \\
\hline Bacitracin (BAC) & $1-64$ & & & & 2 & & & & 2 & & 2 & 44 & $>64$ & $>64$ \\
\hline Cephalotin (CF) & $1-32$ & & & & 32 & 3 & 2 & 2 & 2 & 3 & & 6 & 1 & $>64$ \\
\hline Chlortetracycline (CTET) & $0.25-8$ & & 17 & 2 & 7 & 6 & 6 & 4 & & & & 8 & 1 & $>64$ \\
\hline Clindamycin (CLI) & $0.25-16$ & & 36 & 5 & 5 & & & 1 & & & & 3 & 0.25 & 1 \\
\hline Danofloxacin (DANO) & $0.12-4$ & 33 & 2 & & 6 & 5 & 2 & & & & & 2 & 0.12 & 0,12 \\
\hline Enrofloxacin (ENRO) & $0.12-4$ & 44 & 1 & 2 & 1 & 1 & & & & & & 1 & 0.12 & 0.25 \\
\hline Erythromycin (ERY) & $0.25-64$ & & 21 & 2 & 5 & 3 & 4 & 4 & 5 & 2 & & 4 & 1 & 32 \\
\hline Florfenicol (FFC) & $0.12-8$ & 4 & 1 & & 6 & 7 & 20 & 3 & & & & 9 & 4 & $>64$ \\
\hline Gentamicin (GEN) & $0.5-8$ & & & 1 & & 2 & 4 & 2 & & & & 41 & $>64$ & $>64$ \\
\hline Kanamycin (KAN) & $0.5-2$ & & & 43 & 5 & & & & & & & 2 & 0.5 & 1 \\
\hline Lincomycin (LCM) & $0.12-1$ & 15 & 6 & 4 & 4 & & & & & & & 21 & 0.5 & $>64$ \\
\hline Neomycin (NEO) & $0.5-32$ & & & 16 & 4 & 10 & 10 & 5 & 4 & 1 & & & 2 & 8 \\
\hline Oxytetracycline (OXY) & $0.25-16$ & & 17 & 6 & 9 & 5 & 2 & 4 & 1 & & & 6 & 1 & $>64$ \\
\hline Penicillin (PEN) & $0.12-8$ & 17 & 8 & 5 & 5 & 5 & & 4 & 1 & & & 5 & 0.25 & 16 \\
\hline Spectinomycin (SPE) & $2-64$ & & & & & 26 & 4 & 6 & 7 & & 4 & 3 & 2 & 64 \\
\hline SXT & $0.5-2$ & & & 24 & 7 & 11 & & & & & & 8 & 1 & $>64$ \\
\hline Tetracyclin (TCN) & $0.12-64$ & 24 & 5 & 4 & 5 & 4 & 3 & 2 & 1 & 1 & & 1 & 0.25 & 8 \\
\hline Tiamulin (TIA) & $0.25-32$ & & 5 & & 1 & 7 & 8 & 5 & 10 & 2 & & 12 & 8 & $>64$ \\
\hline Tilmicosin (TIL) & $0.5-32$ & & & 30 & 1 & 5 & 2 & 4 & 2 & & & 6 & 0.5 & $>64$ \\
\hline Tylosin tartrate (TYLT) & $1-64$ & & & & 6 & 4 & 3 & 6 & 12 & 8 & 1 & 10 & 16 & $>64$ \\
\hline
\end{tabular}

Table 3. Antimicrobial susceptibility of clinical isolates according to their serovar

\begin{tabular}{lcc}
\hline Clinical isolate serovar & \multicolumn{2}{c}{ Susceptibility profile } \\
\cline { 2 - 3 } & High susceptibility & High resistance \\
\hline SV 1 & CLIN, KAN & BAC, GEN \\
SV 2 & CTET, CLI, ENRO, NEO, PEN & BAC \\
SV 4 & DANO, ENRO, KAN & BAC, GEN \\
SV 5 & CF, CLI, ENRO & BAC, GEN \\
SV 12 & ENRO, KAN & BAC, GEN \\
SV 14 & CF, CLI, ENRO, KAN, SPE & BAC, GEN \\
NT & ENRO, KAN & BAC, GEN
\end{tabular}

Antimicrobial susceptibility profiles of clinical isolates were compared for each serovar. The antimicrobials were indicated as highly $\left(\mathrm{MIC}_{90} \leq 0.5\right.$ $\mu \mathrm{g} / \mathrm{ml}$ ) or not effective ( $\left.\mathrm{MIC}_{90}>64 \mu \mathrm{g} / \mathrm{ml}\right)$. $\mathrm{N}=$ non-typable, $\mathrm{BAC}=$ bacitracin, $\mathrm{CLI}=$ clindamycin, $\mathrm{CF}=$ cephalotin, $\mathrm{CTET}=$ chlortetracycline, DANO $=$ danofloxacin, ENRO = enrofloxacin, GEN = gentamicin, $\mathrm{KAN}=$ kanamycin, $\mathrm{NEO}=$ neomycin, $\mathrm{SPE}=$ spectinomycin.

te et al. 2007, Zhou et al. 2010). According to our findings, DANO and ENRO represent the most successful choice of agents for the treatment of $H$. parasuis-affected piglets. Previous observations (Cheng et al. 2012) have stated that the hereby-reported sensitivity to fluoroquinolones is likely to be the result of a successful regulation of the administration of these antimicrobials. The bioavailability of antibiotics strongly depends on the route of administration, animal species and physiological status (Lopez-Cadenas et al. 2013). Fluoroquinolone therapy must be administered with care since several adverse events, including tendinitis and central nervous system-related effects, have been documented in humans (Owens \& Ambrose 2005). Also, several mechanisms of fluoroquinolone-induced resistance have been identified: mutation in topoisomerase II and IV genes, overexpression of efflux pumps, decreased per- meability of cell wall and changes in the putative virulence factors (Jacoby et al. 2013, Zhang et al. 2013). Taking into account that resistance to fluoroquinolones has been found in clinical and environmental isolates and resistance appears to be spreading (Jacoby et al. 2013, Piddock 1999), they should be carefully and strategically used to limit the surge of resistant isolates.

With regard to the aminoglycosides, the results varied according to the antibiotic tested. Namely, a high susceptibility was observed to KAN while a high resistance was seen to GEN. The reason of KAN and GEN inducing opposite outcome in these H. parasuis isolates is not clear. Aminoglycosides primarily target the ribosome but they also perform a wide variety of biological activities (Davies and Wright 1997). Several mechanisms can impair aminoglycosides action: decrease drug uptake or accumulation in the bacterium and activation of bacterial enzymes that inactivate the antibiotic (Shaw et al. 1993). Aminoglycoside-modifying enzymes are usually encoded by plasmids but they are also connected with transponsable elements integrated into the genome (Mingeot-Leclercq et al. 1999). Among these enzymes, $N$-acetyltransferases confer resistance to GEN but do not to KAN (Shaw et al. 1993). One can speculate that a wider use of GEN in the local swine husbandries selected a GEN-resistant strain encoding for a plasmid resistance gene. However, antibiotic susceptibility profile of reference strains indicated a similar figure, suggesting perhaps that the gene(s) of resistance might be integrated into the genome. A good susceptibility was found for the other aminoglycosides, namely NEO and SPE. The $\mathrm{MIC}_{90}$ of SPE $(64 \mu \mathrm{g} /$ $\mathrm{ml}$ ) was the same as those reported for Spanish, British (De la Fuente et al. 2007) and Danish clinical isolates (Aarestrup et al. 2004) while the $\mathrm{MIC}_{50}$ was lower $(2 \mu \mathrm{g} / \mathrm{ml})$ in our 
study compared to the previous ones. Importantly, no field isolates were sensitive to NEO beyond the breakpoint in the present investigation.

The results obtained for BAC are in agreement with those reported in the literature (Hovig and Aandahl 1969). The high resistance observed to GEN and BAC in both clinical isolates and reference strains encourage us to propose that GEN and BAC (at $0.25 \mu \mathrm{g} / \mathrm{ml}$ ) could be used to compose a selective medium for $H$. parasuis isolation in the laboratory.

Clinical isolates were susceptible to CLI $\left(\mathrm{MIC}_{90}\right.$ of 1 $\mu \mathrm{g} / \mathrm{ml}$ ) but resistant to LCM ( $\mathrm{MIC}_{90}>64 \mu \mathrm{g} / \mathrm{ml}$ ), another member of the lincosamide family. Interestingly, Spanish field isolates showed the same bimodal population of susceptibility to LCM (De la Fuente et al. 2007), suggesting an ongoing process of acquired resistance. Similarly, the bimodal distribution of CF population and the tailing of AMP and PEN (all $\beta$-lactams) indicate a possible development of a certain degree of resistance. In other studies (Wissing et al. 2001, Aarestrup et al. 2004, Zhou et al. 2010, Nedbalcova \& Kucerova 2013), susceptibility to $\beta$-lactams varied from a high susceptibility to PEN in British isolates (De la Fuente et al. 2007) to the growing resistance to AMP in Spanish strains (De la Fuente et al. 2007, San Millan et al. 2007).

The resistance of Brazilian isolates to ERY and TIL (30\% and $16 \%$ respectively) was lower than the $40 \%$ reported for Spanish isolates (De la Fuente et al. 2007). However, British (De la Fuente et al. 2007), Danish (Aarestrup et al. 2004) and Chinese (Zhou et al. 2010) field strains showed scarce or no resistance to ERY and TIL, while Czech isolates were highly resistant to ERY (Nedbalcova et al. 2006) but not to TIL (Nedbalcova \& Kucerova 2013). No breakpoint was available for TYLT. However, the considerably high $\mathrm{MIC}_{50}$ and MIC $_{90}$ of Brazilian isolates $(16$ and $>64 \mu \mathrm{g} / \mathrm{ml}$ respectively) suggest the existence of resistant isolates to this compound. The highest resistance to OXY was found amongst Spanish isolates (De la Fuente et al. 2007), followed by the moderate resistance in the clinical isolates of our study and the low or no resistance of British and Danish isolates (Aarestrup et al. 2004, De la Fuente et al. 2007). The susceptibility to TCN of Brazilian isolates was in line with that reported for H. parasuis in Czech Republic (Nedbalcova \& Kucerova 2013).

All clinical isolates from previous studies (Aarestrup et al. 2004, De la Fuente et al. 2007, Zhou et al. 2010, Nedbalcova \& Kucerova 2013) had no resistance to FFC. However, in the present study, $24 \%$ of isolates displayed resistance to FFC, and other 20 isolates were susceptible to the highest dose before the breakpoint $(4 \mu \mathrm{g} / \mathrm{ml})$, which might indicate the development of $H$. parasuis resistances to this antibiotic. A similar pattern was observed for SXT, to which 24 isolates were susceptible to the concentration just before the breakpoint $(0.5 \mu \mathrm{g} / \mathrm{ml})$. A growing resistance to this compound has been found in Danish (Aarestrup et al. 2004), British (De la Fuente et al. 2007), Chinese (Zhou et al. 2010) and especially among Spanish isolates, and reached 53.3\% resistance (De la Fuente et al. 2007). However, no resistance to this antimicrobial agent was found in Czech isolates (Nedbalcova \& Kucerova 2013). Finally, we observed a high resistance $(48 \%)$ to TIA, similar to that found in Spanish isolates while British and Czech ones were susceptible (De la Fuente et al. 2007, Nedbalcova \& Kucerova 2013).

According to our results, antimicrobial agents could be divided in 3 groups: a) a "low efficiency" group that included BAC, GEN, LCM and TIA; b) a "highly effective" group composed of AMP, CLI, DANO, ENRO, NEO and PEN (resistances ranging from 0 to $10 \%$ ), and therefore recommended for use against $H$. parasuis infection in Brazil; and $c$ ) an "intermediary group" to which field isolates showed a moderate resistant, which included the remaining 11 antimicrobials used in this study, with a range of resistance from $11-40 \%$. Antimicrobials that are currently used to control and treat $H$. parasuis outbreaks in pig farms are $\beta$-lactams (AMP and PEN), phenicols (FFC), macrolides (ERY, TIL, TYLT), potentiated sulphonamides (SXT) and tetracyclines (CTET, OXY and TCN) (Dayao et al. 2014). According to the susceptibility profiles obtained in our study, all antimicrobials used for GD clinical treatment belong to the intermediary group, with the exception of PEN. This mild resistance might be caused by the presence and spreading of resistance genes in plasmids carried by $H$. parasuis, as has been reported for tetracyclines and $\beta$-lactams (Lancashire et al. 2005, San Millan et al. 2007), or by other mechanisms yet to be identified.

\section{CONCLUSIONS}

The susceptibility profile of Haemophilus parasuis clinical isolates from South Brazil swine husbandries indicates that they have acquired different degrees of resistance to antimicrobial agents. Probably, the preferential use of certain antibiotics during GD outbreaks in swine herds have selected some strains resistances to these molecules.

$H$. parasuis reference strains share similar antimicrobial susceptibility patterns. This observation could indicate that the resistance acquired to some compounds might be carried by transposons and thereby integrated in the genome.

Our results indicate the importance of a careful use of antimicrobial agents to treat GD in order to avoid the development of new resistant isolates. For this reason, a periodic survey is advised to monitor the evolution of antimicrobial resistances to $H$. parasuis.

Acknowledgments.- This work was supported by National Counsel of Technological and Scientific Development, Brazil (CNPq, grant 485807/2013-0). M.M and J.A.G were recipient of a postdoctoral fellowship from the Coordination for the Improvement of Higher Education Personnel (CAPES). M.S.L and J.P.E were supported by a Master fellowship from the University of Passo Fundo Foundation.

Conflict of Interest.- The authors declare they have no conflict of interest.

\section{REFERENCES}

Aarestrup F.M., Oliver Duran C. \& Burch D.G. 2008. Antimicrobial resistance in swine production. Anim. Health Res. Rev. 9:135-148.

Aarestrup F.M., Seyfarth A.M. \& Angen 0. 2004. Antimicrobial susceptibility of Haemophilus parasuis and Histophilus somni from pigs and cattle in Denmark. Vet. Microbiol. 101:143-146.

Cheng A.C., Turnidge J., Collignon P., Looke D., Barton M. \& Gottlieb T. 2012. Control of fluoroquinolone resistance through successful regulation, Australia. Emerg. Infect. Dis. 18:1453-1460. 
CLSI 2013. Performance Standards for Antimicrobial Disk and Dilution Susceptibility Tests for Bacteria Isolated from Animals: approved standard. 4th ed. CLSI Document VET01-A4. Clinical and Laboratory Standards Institute, Wayne, Pennsylvania.

Costa-Hurtado M. \& Aragon V. 2013. Advances in the quest for virulence factors of Haemophilus parasuis. Vet. J. 198:571-576.

Davies J. \& Wright G.D. 1997. Bacterial resistance to aminoglycoside antibiotics. Trends Microbiol. 5:234-240.

Dayao D.A., Kienzle M., Gibson J.S., Blackall P.J. \& Turni C. 2014. Use of a proposed antimicrobial susceptibility testing method for Haemophilus parasuis. Vet. Microbiol. 172:586-589.

De la Fuente A.J., Tucker A.W., Navas J., Blanco M., Morris S.J. \& Gutierrez-Martin C.B. 2007. Antimicrobial susceptibility patterns of Haemophilus parasuis from pigs in the United Kingdom and Spain. Vet. Microbiol. 120:184-191.

Hovig B. \& Aandahl E.H. 1969. A selective method for the isolation of $\mathrm{Ha}$ emophilus in material from the respiratory tract. Acta Pathol. Microbiol. Scand. 77:676-684.

Howell K.J., Peters S.E., Wang J., Hernandez-Garcia J., Weinert L.A., Luan S.L., Chaudhuri R.R., Angen O., Aragon V., Williamson S.M., Parkhill J., Langford P.R., Rycroft A.N., Wren B.W., Maskell D.J., Tucker A.W. \& Consortium B.R.T. 2015. Development of a multiplex PCR assay for rapid molecular serotyping of Haemophilus parasuis. J. Clin. Microbiol. 53:3812-3821.

Jacoby G.A., Corcoran M.A., Mills D.M., Griffin C.M. \& Hooper D.C. 2013. Mutational analysis of quinolone resistance protein QnrB1. Antimicrob. Agents Chemother. 57:5733-5736.

Lancashire J.F., Terry T.D., Blackall P.J. \& Jennings M.P. 2005. Plasmid-encoded Tet B tetracycline resistance in Haemophilus parasuis. Antimicrob. Agents Chemother. 49:1927-1931.

Lorenson M.S., Miani M., Guizzo J.A., Barasuol B., Martínez-Martínez S., Ferri E.F.R., Gutiérrez Martín C.B., Kreutz L.C. \& Frandoloso R. 2016. Altered indirect hemagglutination method for easy serotyping of Haemophilus parasuis. Arq. Bras. Med. Vet. Zootec. 69:15-21.

Lopez-Cadenas C., Sierra-Vega M., Garcia-Vieitez J.J., Diez-Liebana M.J., Sahagun-Prieto A. \& Fernandez-Martinez N. 2013. Enrofloxacin: pharmacokinetics and metabolism in domestic animal species. Curr. Drug Metab. 14:1042-1058.
Mingeot-Leclercq M.P., Glupczynski Y. \& Tulkens P.M. 1999. Aminoglycosides: activity and resistance. Antimicrob. Agents Chemother. 43:727737.

Nedbalcova K. \& Kucerova Z. 2013. Antimicrobial susceptibility of Pasteurella multocida and Haemophilus parasuis isolates associated with porcine pneumonia. Acta Veterinaria Brno 82:3-7.

Nedbalcova K., Satran P., Jaglic Z., Ondriasova R. \& Kucerova Z. 2006. Haemophilus parasuis and Glasser's disease in pigs: a review. Veterinarni Medicina 51:168-179.

Oliveira S., Galina L. \& Pijoan C. 2001. Development of a PCR test to diagnose Haemophilus parasuis infections. J. Vet. Diagn. Invest. 13:495-501.

Owens Jr R.C. \& Ambrose P.G. 2005. Antimicrobial safety: focus on fluoroquinolones. Clin. Infect. Dis. 41(Suppl.2):S144-157.

Piddock L.J. 1999. Mechanisms of fluoroquinolone resistance: an update 1994-1998. Drugs 58(Suppl.2):11-18.

Rafiee M. \& Blackall P.J. 2000. Establishment, validation and use of the Kielstein-Rapp-Gabrielson serotyping scheme for Haemophilus parasuis. Aust. Vet. J. 78:172-174.

San Millan A., Escudero J.A., Catalan A., Nieto S., Farelo F., Gibert M., Moreno M.A., Dominguez L. \& Gonzalez-Zorn B. 2007. Beta-lactam resistance in Haemophilus parasuis Is mediated by plasmid pB1000 bearing blaROB-1. Antimicrob. Agents Chemother. 51:2260-2264.

Shaw K.J., Rather P.N., Hare R.S. \& Miller G.H. 1993. Molecular genetics of aminoglycoside resistance genes and familial relationships of the aminoglycoside-modifying enzymes. Microbiol. Rev. 57:138-163.

Shojaee Aliabadi F. \& Lees P. 2003. Pharmacokinetic-pharmacodynamic integration of danofloxacin in the calf. Res. Vet. Sci. 74:247-259.

Wissing A., Nicolet J. \& Boerlin P. 2001. [The current antimicrobial resistance situation in Swiss veterinary medicine]. Schweiz. ArchTierheilkd 143:503-510.

Zhang Q., Liu J., Yan S., Yang Y., Zhang A. \& Jin M. 2013. Fluoroquinolone-resistant Haemophilus parasuis isolates exhibit more putative virulence factors than their susceptible counterparts. J. Clin. Microbiol. 51:31303131.

Zhou X., Xu X., Zhao Y., Chen P., Zhang X., Chen H. \& Cai X. 2010. Distribution of antimicrobial resistance among different serovars of Haemophilus parasuis isolates. Vet. Microbiol. 141:168-173. 